\title{
CASE STUDY FOR ESTIMATION OF THE AMOUNT OF CONTAMINANTS STORED IN SOIL IN AN INDUSTRIAL AREA
}

\section{GERGŐ KARANCSI ${ }^{1 *}$, EMŐKE KISS ${ }^{2}$, DÁNIEL BÉRES ${ }^{1}$, DÁNIEL BALLA ${ }^{1}$}

\author{
${ }^{1}$ University of Debrecen, Department of Computer Graphics and Image Processing \\ ${ }^{2}$ University of Debrecen, Department of Landscape Protection \\ and Environmental Geography \\ *Email: karigeri@mailbox.unideb.hu
}

Received 5 March 2021, accepted in revised form 15 June 2021

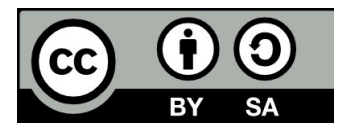

\begin{abstract}
One of the main sources of contaminants in the soil is industrial activity which has become one of the major environmental problems of the last few decades. The development of geoinformatics as well as the introduction of standards and regulations has led to a decreased risk of soil contamination and the cost-effective optimization of remediation activities. Based on the above, the aim of our study is to demonstrate the geoinformation processing of the remediation performed in an industrial area located in the Great Hungarian Plain, with special regard to the estimation of the amount and spread of the contaminants accumulated in the soil. In order to reveal the lithological and hydrogeological properties of the investigated area and the environmental status of the underground areas, we performed a large number of shallow land drillings (115). During the field sampling, 1000-1500 grams of samples were collected from the drill bit and were processed in an accredited laboratory. Based on the concentration and volume models created it can be concluded that with the estimations performed via modeling, we were able to locate the most critical areas from the standpoint of contamination. It was revealed that the focal point of the contaminants accumulated in the soil was in the central part of the investigated area. Furthermore, the model demonstrated the effect of lithological factors, since contaminants tend to accumulate more heavily in cohesive soils compared to porous rocks. The extent of contaminant concentration in the aquifer increased with decreasing depth; however, after reaching the floor clay the extent of contaminant concentration began to decrease. The lithological layer closest to the surface contained the most contaminants.
\end{abstract}

Keywords: contamination, GIS, soil, 3D model

\section{Introduction}

One of the most important tasks of environmental geology is to identify and evaluate the contaminants located in underground environments in various states of matter, as well as to determine the amount of these contaminants (Báldi, 2003; Kozák \& Csámer, 2011). However, the tools of analytical and applied geology alone are not sufficient for this and therefore methods and results from other disciplines should be used. In accordance with the above, in order to create a visual representation of the spatial aspects of the data collected, we have to rely on a field referred to as thematic cartography (Albert 2004, 2005). Due to the development of what Schütze (2007) labelled 
the "geoinformatic revolution" the display/ interpretation of geological maps using GIS software has opened up new horizons (Turczi et al. 2004, Zichar 2013), as a result of which the number of scientific papers published in the field is growing year by year (Szabó \& Czellér, 2009; Mcintosh \& Encs, 2016; Zichar 2012 and 2016; Jankó \& Szabó, 2018).

Contaminants accumulating in the soil due to industrial activities is a serious environmental issue which needs to be managed by society (MacCormack, 2005; Wycisk et al., 2009; Marshall et al., 2020). Uncontrolled emissions of contaminants lasting for decades leads to severe environmental pollution which can only be managed by expensive remediation measures (Ahmed 2009; Mustak et al., 2015; Fischer, 2008, Szabó et al., 2016). The amount of contaminants occurring under the surface in various states of matter can nowadays be determined with several geoinformatics software programmes, which can be used to identify the sources and the spread of contaminants in order to facilitate the remediation process (Yang et al. 2004; Kátai 2008; Hürkamp et al. 2009).

Based on the above, the aim of our study is to demonstrate the geoinformation processing of the remediation performed in an industrial area located on the Great Hungarian Plain, with special regard to the estimation of the amount and spread of the contaminants accumulated in the soil.

\section{Material and Methods}

\section{Study area}

The investigated area of the environmental remediation is about $20000 \mathrm{~m}^{2}$. Its longer side is 200 meters with a North-South orientation, while its shorter side is 100 meters with an East-West orientation. The study area had been used as an industrial area. In its surroundings, there is a residential area to the North, while to the East, South and West there are also industrial areas. The landscape has already started to be reshaped due to surface reconstruction works carried out before the remediation measures. Consequently, the original landscape is heavily disturbed and artificially constructed, and mostly has thick ground cover. Its original land cover has only remained in the Northern part in small trace areas. The slope of the land is oriented from the buildings to the lower parts of the area, which noticeably affects the movement of the groundwater and the contaminants stored in it. As a consequence of the buildings and other artifacts the proportion of the area which is covered (asphalt, concrete) is high. As the area had been an industrial site before, it had a well-developed infrastructure (e.g. a sewer system and other pipeline systems and their collection units). The soil and groundwater were affected mostly by the acidic and fecal matter contaminants originating from the sewage system and its collection units. These contaminants could leak from concurrently damaged, corroded or inappropriate insulation, and directly contaminate the surrounding underground environment.

In the industrial site, production and environmental remediation are continuously ongoing, with the exception of the study area. Considering the above, we were working with sensitive data and we could only include partial information in this study. The number of the compounds investigated was approximately 60 (e.g. total mineral hydrocarbon, BTEX compounds, halogenated aliphatic and aromatic hydrocarbons, general hydrochemical properties and toxic metals dissolved in groundwater) and most of them were of organic origin, with a limited amount of inorganic materials. Therefore, the organic contaminants were considered as the reference. All of these compounds were defined by a unique " $\mathrm{B}$ " contamination limit and " $D$ " remediation limit. For the sake of simplicity, during the modeling the sum of the contaminants was used. In the investigation, the horizontal extension of the compounds exceeding the " $\mathrm{D}$ " limit, was an important factor in the determination of 
the contaminated area. By cross-referencing the grids of various compounds exceeding the remediation limit value, we were able to determine a unified contaminated area. In order to reveal the lithological and hydrogeological properties of the investigated area and the environmental status of the underground areas, we performed a high number of shallow drillings (115). During the field sampling, we collected an adequate number of water samples from the newly established wells (1L from TPH, $1 \mathrm{~L}$ from ÁVK, 0.5L from BTEX, 0.5L from VOCL aliphatic compounds, 0.5L from VOCL aromatic compounds and $0.2 \mathrm{~L}$ from toxic metals). The collected samples were processed in an accredited laboratory (Internet 1 ).

\section{Field sampling}

In order to reveal the lithological and hydrogeological properties of the investigated area and the environmental status of the underground areas, we performed 115 shallow land drillings. During the field sampling 1000-1500 grams of samples were collected from the drill bit and were processed in an accredited laboratory.

\section{Calculation of the hydrogeological parameters}

\section{Volumetric density}

Calculation of volumetric is density is necessary to determine the amount of contamination bonded to soil particles. This is the metric which is most commonly used to express the compactness and looseness of the soil and refers to the dry mass of the soil per unit volume in its original state (Internet2).

\section{Effective porosity}

One of the area-specific parameters required for the modelling is effective porosity (n0). This indicates the amount of water stored in the pore space of the rock which is not bound to soil particles and can be removed gravitationally (Table 1 ). The value of the parameter can be determined through laboratory tests; however, according to an empirical relationship, in practice, effective porosity can be calculated based on the filtration coefficient (Kovács - Szanyi, 2005).

The filtration coefficient, which describes the hydraulic conductivity of objects, is also an area-specific property which can be determined by several methods. One possible way to achieve this is to perform a pump test in the well. However, if the results of the pump test are not available, conductivity data calculated from the results of laboratory experiments or particle distribution tests can be also used.

Table 1. Effective Porosity Values of Lithological Objects

\begin{tabular}{cc}
\hline Lithology & Effective Porosity $(-)$ \\
\hline clay & 0.046 \\
clayey silt & 0.103 \\
bedrock gravel & 0.114 \\
replenishment & 0.080 \\
sand & 0.104 \\
sandy silt & 0.094 \\
silt & 0.046 \\
silty clay & 0.117 \\
silty sand & 0.046 \\
solid cover (asphalt, concrete) & 0.103 \\
soil & 0.114 \\
\hline
\end{tabular}




\section{Estimation of the amount of contamination stored in the soil, using RockWorks}

The amount of contamination stored in the soil (M) can be calculated using the following empirical formula:

$$
M_{\text {total contamination }}=V_{v} \sum_{i=1}^{n} \rho_{i} c_{i}
$$

Where $\mathrm{V}$ is the volume of the voxel, $\mathrm{p}$ is the volumetric density calculated per the given lithological unit, and $\mathrm{c}$ is the concentration measured in the given location:

$$
M_{\text {total contamination }}=V_{\rho 1} \rho_{1} c_{1}+V_{\rho 2} \rho_{2} c_{2}+\ldots \ldots+V_{\rho n} \rho_{n} c_{n}
$$

That is, since

$$
\begin{gathered}
V_{\rho 1}=V_{\rho 2}=\ldots \ldots=V_{\rho n} \\
M_{\text {total contamination }}=V_{p 1}\left(\rho_{1} c_{1}+\rho_{2} c_{2}+\ldots \ldots+\rho_{n} c_{n}\right)
\end{gathered}
$$

\section{Estimation of the amount of contamina- tion stored in the soil, using Surfer}

The mass of contaminants stored in the soil (M) can be calculated using the following empirical formula:

$$
M=\int V * \rho * c * d x d y
$$

Where $\mathrm{V}$ is the volume, $\mathrm{p}$ is the volumetric density calculated per the given lithological unit, and $\mathrm{c}$ is the concentration measured in the given location.

\section{GIS methods}

With regards to the determination of the contaminated area, the horizontal extension of the compounds exceeding the " $D$ " limit was an important factor. By cross-referencing the grids of various compounds exceeding the remediation limit value, we were able to determine a unified contaminated area.

In order to estimate the amount of contamination stored in the soil we created a contaminant concentration model and a volumetric density solid model using RockWorks, and then we multiplied the product of these with the volume of the voxel. The parameters of the model created for the investigated area are the following: $5.0 \mathrm{~m} \times 5.0 \mathrm{~m} \times 0.2 \mathrm{~m}$, therefore its volume is $5 \mathrm{~m}^{3}$. During the model building, the upper filter was composed of the grid created from the surface of the investigated area, while the lower filter was the lower, connected clay layer/grid of the aquifer, that is the surface connecting the total depths of the shallow drilling holes, for which anisotropic algorithm was used. Then we compiled the contaminant concentration solid model and the model depicting the 3D distribution of the volumetric density of the investigated area (Albert, 2009).

Next, we created the contaminant concentration maps of the investigated area per the given depth units in the Surfer software environment, for which we used the natural neighbor geostatistical method. After creating the contaminant distribution maps, we had to build the volumetric density distribution maps of the investigated area, which also needed to be created per the given depth units. After the development and assessment of the contaminant concentration, the extent of the contamination and the volumetric density distributions, we only had to perform the multiplication by the

Fig. 1. Process of modeling

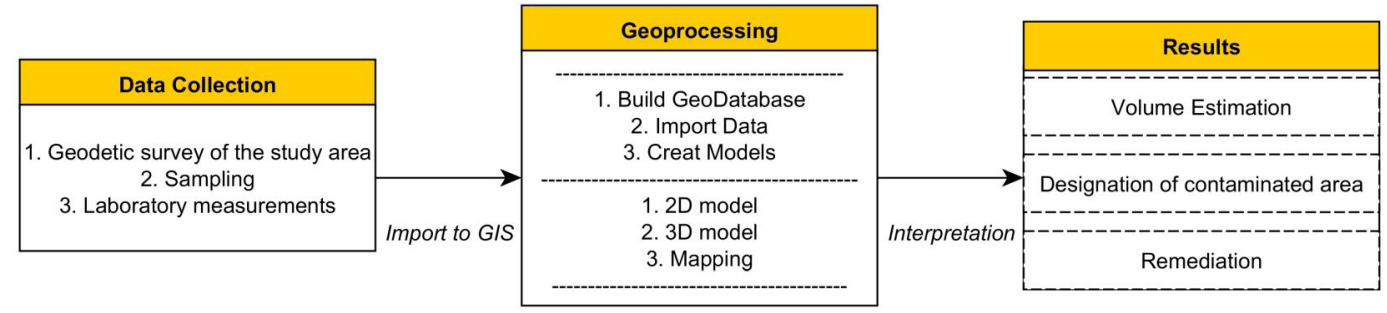


layer depth. Since we used a 1 meter depth unit when working with the aforementioned data, the height value was set as 1 in each case. However, since the 5-6 meter depth unit is not complete, here we had to perform separate calculations. In order to determine this, we subtracted the entire 1 meter depth layers from the total depth of the shallow drilling, which resulted in the depth of the "incomplete layer."

\section{Results}

\section{The lithological model of the sample area}

The placement of the drilling holes located in the area and the layers with respect to drilling holes are demonstrated in Figure 2. The interpolated model created from the sampling points is demonstrated in Figure 3.

The lithological models demonstrate the layout of the investigated area. The compiled model reveals that the upper, approximately 2 meter layer (between 94.0 and 92.0 meters) is an anthropogenic, disturbed area. The fact that anthropogenic effects impacted this depth range is well represented by the presence of the foundation of tank parks and smaller buildings, as well as the development of public infrastructure and various industrial water and pressure pipes.

The depth range between 92.0 and 90.0 serves as an aquifer because of its sandy, sandy-silty, silty-porous character.

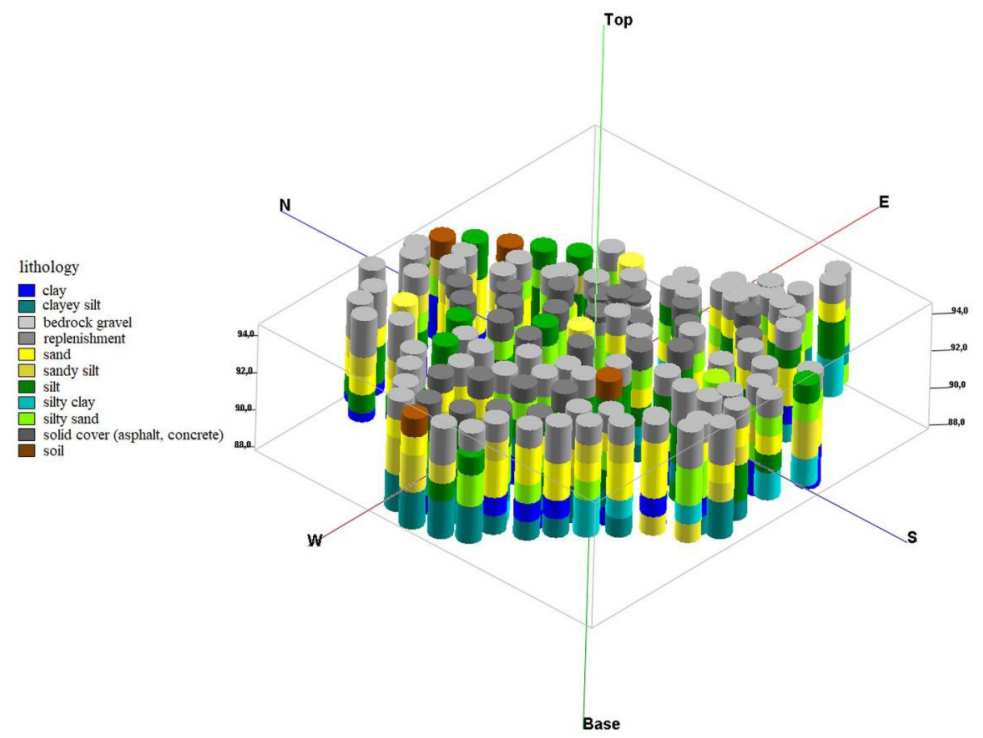

Fig. 2. 3D drilling layers of the points located in the investigated area (with 10x vertical exaggeration)
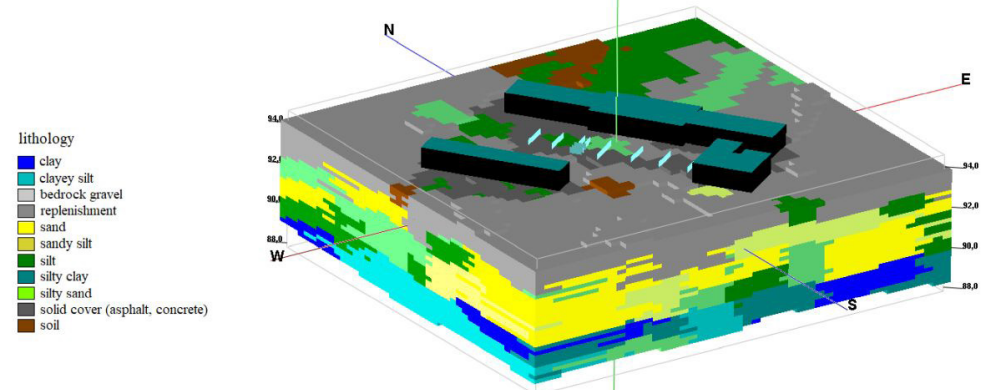

Fig. 3. 3D lithological model of the sample area created from drilling data with buildings and artefacts (with 10x vertical exaggeration) 
Table 2. The number and percentage distribution of the lithological types of the investigated area

\begin{tabular}{ccc}
\hline Lithology & Volume $\left(\mathrm{m}^{3}\right)$ & Volume (\%) \\
\hline clay & 28210 & 11 \\
clayey silt & 15360 & 6 \\
bedrock gravel & 30 & 0.01 \\
replenishment & 37895 & 15 \\
sand & 50785 & 20 \\
sandy silt & 21620 & 8.5 \\
silt & 44425 & 17.5 \\
silty clay & 16550 & 6.5 \\
silty sand & 32080 & 12.5 \\
solid cover (asphalt, concrete) & 6085 & 2.5 \\
soil & 1405 & 0.5 \\
\hline$\sum$ & 254445 & 100 \\
\hline
\end{tabular}

The next, well-defined layer is located between 90.0 and 88.0 meters. This is made up of less porous, more compact clay, and clay-silt, such as is found in the first aquifer in the area, significantly affecting the vertical water movement.

The distribution of soil types calculated from the lithological model of the investigated area is shown in detail in Figure 2.

\section{Estimation of the amount and spatial extension of contaminants stored in the soil, using RockWorks}

On the 3D model (Figure 4) created from the concentration of contaminants which were collected from soil samples and analyzed via chemical tests it can be seen that the contamination bonded in the soil can be detected in the central part of the sample area. The source of this contamination is industrial buildings and tank parks as well as the industrial and public pipes connecting these structures. Furthermore, the effects of the lithological factors can be also be seen on the model, because contaminants accumulate more in more compact soil types (clay, claysilt) and less in porous rocks. The exceptions are locations with continuous contamination such as damaged parts of these buildings and broken and corroding pipes.

On the 3D models created from the volumetric density calculations the lithological vertical variability of the sample area can be seen, which increases from top

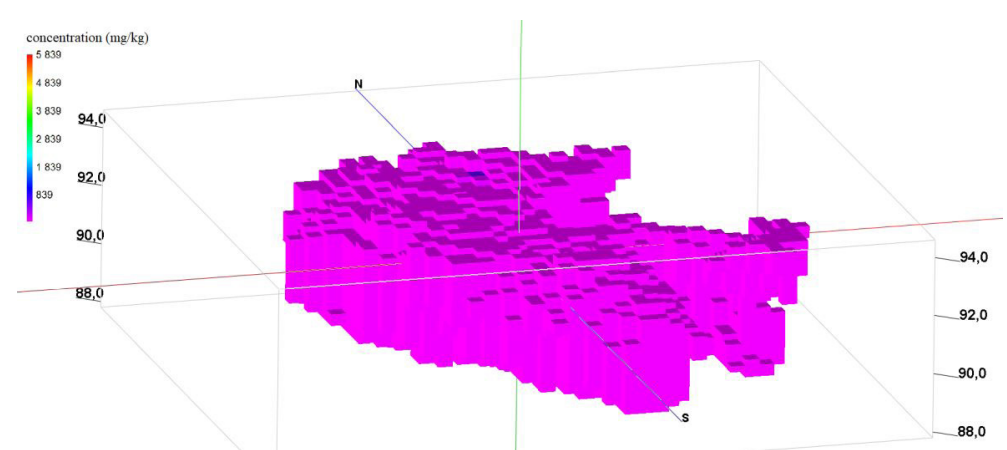

Fig. 4. The contamination distribution $(\mathrm{mg} / \mathrm{kg}$ ) model of the soil of the investigated area (with $10 \mathrm{x}$ vertical exaggeration) 


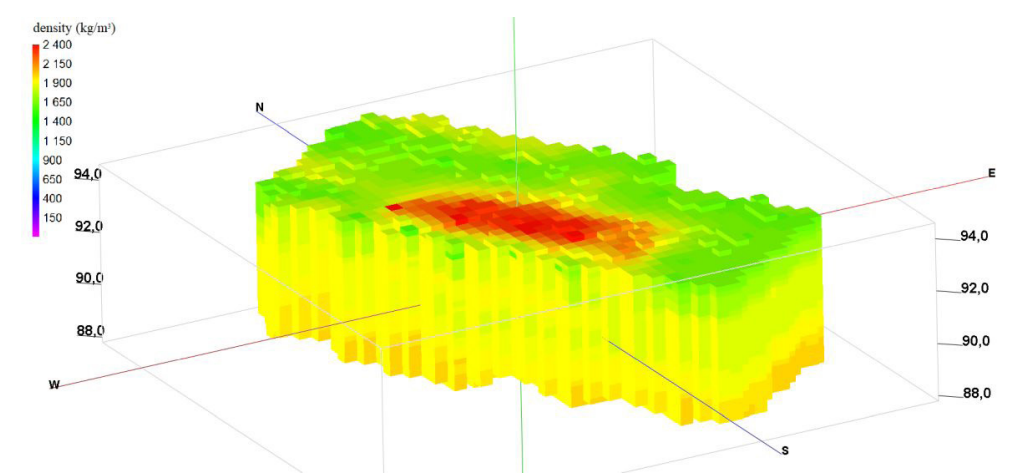

Fig. 5. The volumetric density $\left(\mathrm{kg} / \mathrm{m}^{3}\right)$ of the soil of the investigated area (with $10 \mathrm{x}$ vertical exaggeration)

to bottom (Figure 5), as well as the location of the foundation of the tank park made of concrete and reinforced concrete in the center. Compared to the lithological model, the appearance of this is more homogeneous as well.

Following the compilation of the models we determined the amount of the contaminants. For this, a multiplication had to performed using the abovementioned two solid models. From the results we can see that the total amount of contaminants above the limit value of $2 \mathrm{mg} / \mathrm{kg}$ is $2139300173,22 \mathrm{mg} / \mathrm{m}^{3}$. In order to obtain the amount of contamination stored in the soil of the investigated area, it should be multiplied with the volume of the voxel, that is by $5 \mathrm{~m}^{3}$. The result is 10.7 tons.

\section{Estimation of the amount and spatial extension of contaminants stored in the soil using Surfer}

During the compilation of the models, we created the concentration distribution and volumetric density grids from the investigated area. Since the estimation of the amount of contaminants accumulated and stored in the soil is more difficult than for the ground water, the contaminant distribution maps had to be created per depth unit in such a way that it reflected the depth of the sampling. Consequently, 5 separate surfaces had to be created where the measured mean concentration was assigned to the $\mathrm{x}, \mathrm{y}$ coordinates. In the $1-2 \mathrm{~m}, 3-4 \mathrm{~m}$, and 4-5m depth ranges direct sampling was not performed, but during the modeling omitting these areas would have presented a greater risk of error compared to calculating a mean value from the layers above and below it. The other necessary item for the estimation, the volumetric density, had to be created in a similar way.

We created the contaminant concentration maps regarding the investigated area per the given depth units, for which we used the natural neighbor geostatistical method. The models demonstrate the extent of the contamination in different depth units. It can be observed that the extent of concentration in the aquifer increases with the decrease of depth; however, after reaching the floor clay the extent of contaminant concentration begins to decrease (Figure 6).

We also compiled the volumetric density distribution map for the investigated area per the given depth units (Figure 7). The distribution maps created demonstrate the separation of aquifer and aquifuge, since from 4-5m the volumetric density values increase, therefore the water permeability capacity of the given lithological layer decreases. Close to the surface (1-2m) anthropogenic concrete structures of great size $\left(2400 \mathrm{~kg} / \mathrm{m}^{3}\right)$ can still be observed. 
Based on the models compiled, we calculated the mass of the contaminants stored in the soil, where we multiplied the mean concentration values of the given layer, the mean volumetric densities values, the extent of the contamination and the layer depth. Figure 3 summarizes the amount of contamination stored per depth unit, based on which it can be concluded that most of the contaminants are stored in the upper layer. Furthermore, it should be noted that contamination is also present to a significant degree in the 5-6 $\mathrm{m}$ depth unit.
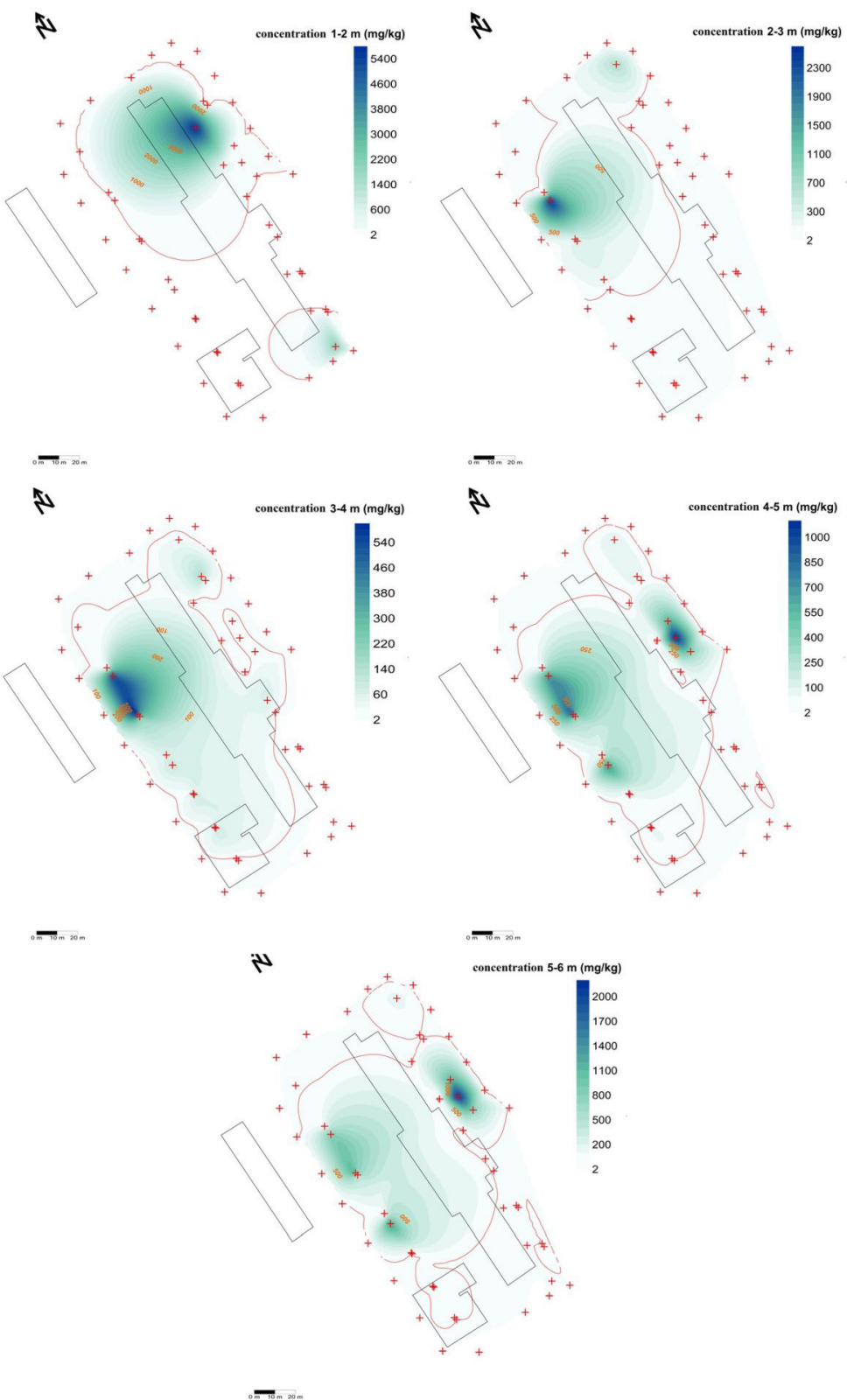

Fig. 6. The distribution maps and the sampling points of the contaminant concentration $(\mathrm{mg} / \mathrm{kg})$ of the investigated area 

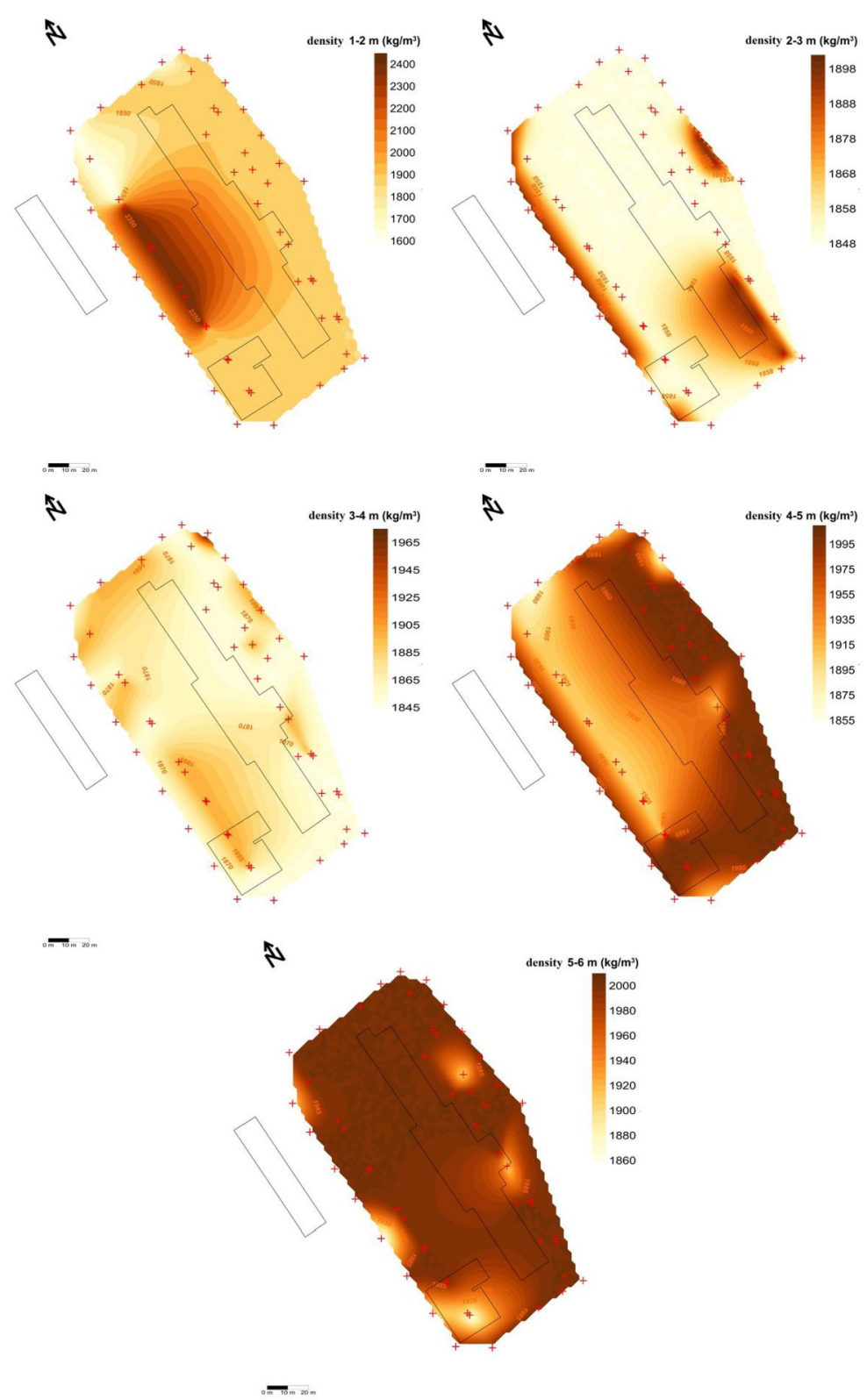

Fig. 7. The distribution maps and the sampling points of the volumetric density $\left(\mathrm{kg} / \mathrm{m}^{3}\right)$ of the investigated area 
Table 3. The amount of contamination stored in the soil in the investigated area

\begin{tabular}{cccc}
\hline \multirow{2}{*}{ Depth } & \multicolumn{3}{c}{ Amount of contaminant } \\
\cline { 2 - 4 } & 6355942419.60 & 6355.90 & $(\mathrm{t})$ \\
\hline $1-2 \mathrm{~m}$ & 3483429791.00 & 3483.40 & 6.4 \\
$2-3 \mathrm{~m}$ & 1394525638.50 & 1394.50 & 3.5 \\
$3-4 \mathrm{~m}$ & 2930174603.90 & 2930.20 & 1.4 \\
$4-5 \mathrm{~m}$ & 2783970338.20 & 2784.00 & 2.9 \\
$5-6 \mathrm{~m}$ & 16948042791.30 & 16948.00 & 2.8 \\
\hline$\Sigma$ & & & 16.9
\end{tabular}

\section{Conclusion}

Based on the models in the industrial area the following conclusions can be drawn:

1. The most contaminated soils are not present in the industrial area after the remediation works; however, in order to complete the remediation process, further follow-ups are required which are currently in progress.

2. The focal point of the contamination bonded in the soil can be detected in the central part of the investigated area. The source of this is activities performed in industrial buildings and tank parks as well as the industrial and public pipes connecting these structures. Furthermore, the effects of the lithological factors can be also be seen on the model, because contaminants accumulate more in more compact soil types (clay, clay-silt) and less in porous rocks. The exceptions are locations with continuous contamination such as damaged parts of these buildings and broken and corroded pipes.

3. The extent of contaminant concentration in the aquifer increases with the decrease in depth; however, after reaching the floor clay the extent of contaminant concentration begins to decrease.

4. Most of the contaminants are stored in the upper layer of the soil. Furthermore, it should be noted that contamination is also present to a significant degree in the 5-6 m depth unit.

5. Based on the estimations performed on the basis of the models, we were able to determine the most critical areas from a contamination point of view, which have been exploited and deposited in hazardous waste dumps and where the location of the exploitation has been filled with inert soil.

\section{Acknowledgments}

This work was supported by the construction EFOP3.6.3-VEKOP-16-2017-00002. The project was supported by the European Union, co-financed by the European Social Fund.

\section{References}

Ahmed, A. A. (2009). Using lithologic modeling techniques for aquifer characterization and groundwater flow modeling of the Sohag area, Egypt. Hydrogeology Journal, 17(5), 11891201.

Albert G. (2004): Földtudományok eredménye „kézzelfoghatóan”: földtani túratérkép. Geodézia és kartográfia, LVI. évf., 2004/7, pp. 27-30.

Albert G. (2005): Töréses szerkezetek modellezési módszerei. A Magyar Állami Földtani Intézet Évi Jelentése, 2004, pp. 97-107.

Albert G. (2009): Háromdimenziós földtani modellek fejlesztésének és megjelenítésének módszerei térinformatikai szemlélettel. Doktori (PhD) értekezés.

Báldi T. (2003). A történeti földtan alapjai. Nemzetei Tankönyvkiadó, Budapest, p. 312.

Fischer, W. (2008). Survey of abandoned industrial sites in the province of Carinthia (Austria) - methodology and results. Landscape \& Environment, 2(2), 170-183. Retrieved from 
https://ojs.lib.unideb.hu/landsenv/article/ view/2260

Hürkamp K. - Raab T. - Völkel, J. (2009): Two and three-dimensional quantification of lead contamination in alluvial soils of a historic mining area using field portable X-ray fluorescence (FPXRF) analysis. Geomorphology, 110, pp. 28-36.

Jankó, J., \& Szabó, G. (2018). Regional Development in the Age of Big Data. Landscape \& Environment, 12(1), 1-9. https://doi.org/10.21120/ $\mathrm{LE} / 12 / 1 / 1$

Kátai J. (2008): Talajtan, Talajökológia. Debrecen, Magyarország : Észak-alföldi Régióért Kht. pp. 1-173.

Kovács B. - Szanyi J. 2005: Hidrodinamikai és transzportmodellezés II (Processing Modflow és Surfer for Windows környezetében). Miskolci Egyetem, Szegedi Tudományegyetem, Gáma-Geo Kft. pp. 27-96.

Kozák M. - Csámer Á. (2001). Környezetgeológia II. Debreceni Egyetem, Debrecen, p. 87.

MacCormack, K. (2005). 3-D Modelling of Quaternary Sediments Within the Dundas Valley, Hamilton, Ontario Using ROCKWORKS 2002.

Marshall, A. S., Richardson, D. R., Wilder, K. A., Scharfenberg, D. C., Holmes, S. M., Chandranand, H., ... \& Tschanz, M. (2020). U.S. Patent Application No. 16/227,370.

Mcintosh, R. W., \& Encs, B. (2016). Rock mass rating in Bükk Mts., N Hungary based on petrophysical parameters and parting conditions. Landscape \& Environment, 10(3-4), 161-168. https://doi. org $/ 10.21120 /$ LE $/ 10 / 3-4 / 9$

Mustak, S., Baghmar, N., \& Singh, S. (2015). Prediction of industrial land use using linear regression and mola techniques: A Case Study of Siltara Industrial belt. Landscape \& Environment, 9(2), 59-70. https://doi.org/10.21120/ $\mathrm{LE} / 9 / 2 / 2$

Oke, A., Sangodoyin, A., Ogedengbe, K., \& Omodele, T. (2013). Mapping of river waterquality using inverse distance weighted interpolation in Ogun-Osun river basin, Nigeria. Landscape \& Environment, 7(2), 48-62.

Ramappa, H. E., \& Muniswamy, D. (2017). Spatial Distribution of Heavy Metals around the Gold Mine Ore Tailings of Hatti, Karnataka State, India. Landscape \& Environment, 11(1), 3544. https://doi.org/10.21120/LE/11/1/4

RockWorks, 2008, User's Manual, 12-348 p.

Schütze E. 2007. Current state of technology and potential of Smart Map Browsing in web browsers. Bremen University of Applied Sciences, Osnabrück.
Szabó, G., \& Czellér, K. (2009). Examination of the heavy metal uptake of carrot (daucus carota) in different soil types. Landscape \& Environment, 3(2), 56-70. Retrieved from https://ojs.lib. unideb.hu/landsenv/article/view/2267

Szabó, G., Bessenyei, É., Hajnal, A., Csige, I., Szabó, G., Tóth, C., ... \& Mester, T. (2016). The use of sodium to calibrate the transport modeling of water pollution in sandy formations around an uninsulated sewage disposal site. Water, Air, \& Soil Pollution, 227(2), 1-13. DOI: https://doi. org/10.1007/s11270-015-2742-6

Turczi G. - Albert G. - Havas G. - Tisza A. (2004): Construction and application of a geological 3D model at the Bátaapáti (Üveghuta) Site. Földtani térmodell építése és alkalmazása a Bátaapáti (Üveghutai) telephelyen. A Magyar Állami Földtani Intézet Évi Jelentése, 2003, pp. 285-298.

Wycisk, P., Hubert, T., Gossel, W., \& Neumann, C. (2009). High-resolution 3D spatial modelling of complex geological structures for an environmental risk assessment of abundant mining and industrial megasites. Computers \& Geosciences, 35(1), 165-182.

Yang C.-S - Kao S.-P. - Lee F.-B. - Hung P.-S. (2004): Twelve different interpolatio methods: a case study of Surfer 8.0. Proceedings of the XXth ISPRS Congress. Istanbul, Turkey, vol. XXXV, pp. 778-785.

Zichar, M. (2012): Geovisualization based upon KML. Journal of Agricultural Informatics 3.1. pp. 1926.

Zichar, M. (2013): Geovisualization-related issues with cognitive aspects. In: 2013 IEEE 4th International Conference on Cognitive Infocommunications (CogInfoCom). IEEE, p. 503-508.

Zichar, M. (2016). Guidelines for cost-effective geovisualization in digital forensics. Landscape \& Environment, 10(3-4), 117-122. https://doi. org/10.21120/LE/10/3-4/3

\section{Internet}

Internet 1: https://net.jogtar.hu/ jogszabaly?docid=a0900006.kvv

Internet2:https://regi.tankonyvtar.hu/hu/tartalom/ tamop425/0010_1A_Book_02_Alkalmazott_ talajtan/ch02.html 